\title{
ZuZANNA TOPOLIŃSKA
}

\section{Derywacja semantyczna (i formalna) od prasłowiańskiego rdzenia *by- na gruncie polskim}

Abstrakt: Artykuł przedstawia rezultaty semantycznej i formalnej derywacji ogólnosłowiańskiego rdzenia *by- (por. polski czasownik być) w języku polskim, bazującej na dwóch różnych komponentach semantycznych: 1. 'istnieć, być gdzieś' i 2. 'być jakimś / kimś'.

Analizy prowadzą do konkluzji, że *by- (w derywatach od być) ma bardzo wysoką frekwencję, zarówno w słownictwie, jak i w tekstach, stanowi więc ważny element polskiego systemu leksykalnego i syntaktycznego.

Słowa klucze: derywacja semantyczna; być

0. Centralnym derywatem od prasłowiańskiego rdzenia *by- jest na gruncie polskim czasownik być, który rozwinął dwie linie derywacji semantycznej (i implikowanej przez nią derywacji formalnej) o podstawowym znaczeniu dla naszego systemu leksykalnego i syntaktycznego. Jedna $\mathrm{z}$ nich to 'istnieć, znajdować się w określonym miejscu w czasie i przestrzeni', a druga: 'być kimś/jakimś, tj. pełnić określone funkcje, mieć określone cechy’1. Postaram się przedstawić tutaj:

1 Notabene ta druga linia nawiązuje bezpośrednio do drugiego rdzenia prasłowiańskiego: *esmb - a więc sieć kategorii gramatycznych czasownika być kontynuuje dwa rdzenie prasłowiańskie, fakt sam w sobie rzadki i zasługujący na uwagę. 
1. nieprefigowany czasownik być i jego derywaty,

a następnie

2. prefigowane derywaty formalne od być oraz ich derywaty nominalne.

1. „Słownikowa” forma morfemu rdzennego by pojawia się w koniugacji czasownika być jedynie $\mathrm{w}$ infinitiwie i w czasie przeszłym, $\mathrm{tj}$. $\mathrm{w}$ formie starego $l$ - participium. Formy z samogłoską nosową i przyrostkiem *de- /*do- w czasie przyszłym i w imperatiwie wywodzą się (cytuję za Słownikiem etymologicznym W. Borysia) ,(...) od pie. pierwiastka czasownikowego *b $u$ - 'stawać się, być', na którym oparte jest psł. byti 'istnieć, żyć; przebywać, znajdować się...”. Z kolei czas teraźniejszy czasownika być wywodzi się od ps. *esmb, *esi, *estb..., a dzisiejsze polskie formy jestem, jesteś, jest... oparte są na formie 3 sg tego czasownika.

Derywaty polskiego być to kondycjonalne by wywodzące się ze starego aorystu, byt 'życie, egzystencja', także niebyt, również bydło - dziś 'trzoda, zwierzęta domowe', w staropolszczyźnie (cytuję za Borysiem) też 'posiadłość; żywot', stąd stp. bydlić 'mieszkać'.

Czasownik wielokrotny od być to bywać, stąd bywały, bywalec 'człowiek, który bywał w wielu miejscach i sytuacjach i umie się znaleźć'.

W etymologicznym (i semantycznym) związku z być pozostaje także (por. Boryś) causativum bawić (gdzieś) 'powodować, że się jest'.

Ciekawą karierę zrobiła kondycjonalna partykuła by, łącząc się z neutralnymi modalnie predykatami spójnikowymi w złożone predykaty spójnikowe o projekcji temporalnej z reguły przyszłej i nacechowanej modalnie, jak aby, żeby, gdyby, choćby...; por. też byle...

2. Czasownik być posiada bogatą serię prefigowanych derywatów:

dobyć pf dobywać ipf w staropolszczyźnie 'zyskać', 'nabyć', 'posiąść', dzisiaj odczuwane jako przestarzałe; stąd dobytek 'majątek, mienie', w dialektach też 'zwierzęta domowe, bydło'. Od dobyć z podwójną prefiksacją mamy dziś, w tym samym znaczeniu: $z$ dobyć pf $\sim$ zdobywać ipf, z derywatami jak zdobycz czy zdobywca; 
nabyć pf nabywać 'kupić, osiągnąć, zyskać', stąd nabytek 'to, co zostało nabyte', a także nabywca;

odbyć pf odbywać ipf (np. drogę, podróż; kurację; drzemkę...) 'przebyć, zakończyć'; por. i derywat odbyt;

przebyć (coś) pf 'pokonać drogę, chorobę...' przebywać (gdzieś) ipf 'znajdować się (gdzieś)'; por. archaiczny dziś derywat przebyt 'pobyt', jak w wieczny przebyt;

przybyć (gdzieś) pf przybywać (dokadś) ipf 'przychodzić, przyjeżdżać (dokądś)', stąd przybysz 'ten, kto przybył', przybytek 'to, co przybyło', a także zapożyczenie z czeskiego (por. Boryś) 'budowla, świątynia, siedlisko czegoś;

ubyć pf ubywać ipf 'zmniejszać się ilościowo', por. ubytek;

wybyć pf wybywać ipf 'wyjść, zniknąć' - dziś używane tylko kolokwialnie;

zabyć pf $\sim$ zabywać ipf przestarzałe, spotykane nadal w dialektach 'zapomnieć zapominać', por. zabytek 'obiekt stanowiący świadectwo epoki, mający wartość historyczną, stąd przymiotnik zabytkowy;

zbyć (kogoś czymś) pf zbywać ipf 'uwolnić się / uwalniać się od kogoś, kto nam się narzuca udzielając mu mało wartej odpowiedzi'; staropolskie 'sprzedać', stąd zbyt 'sprzedaż, rynek sprzedaży, wyprzedaż'; por. też zbyt adv 'za dużo, za wiele', stąd i: zbytecznie 'bez potrzeby, bez pożytku'; por. też bliskoznaczne: pozbyć się (czegoś) - pozbywać się, wyzbyć się (czegoś) wyzbywać się.

Jak wynika z przeprowadzonej analizy, semantyka czasownika być i jego derywatów pokrywa znaczną część aktywności związanych z trwaniem i przemieszczaniem się w przestrzeni tak naturalnej, jak i socjalnej, a sporadycznie przenika i do naszego świata mentalnego. Nie zamieszczam tutaj przeglądu konstrukcji ilustrujących drugą linię derywacji semantycznej być, tj. konstrukcji z serii 'być kimś / być jakimś' - musiałabym w tym celu przywołać wszystkie rzeczowniki i przymiotniki z naszego leksykonu - zadanie niere- 
alne; wystarczy uprzytomnić sobie szeroki wachlarz semantyczny tych konstrukcji, aby stwierdzić, że i pod tym względem być zajmuje pozycję szczególną w inwentarzu naszych czasowników ${ }^{2}$.

\section{Semantic (and formal) derivation from the Common Slavic root *by- in Polish \\ ( s u m m a r y)}

The paper presents the results of the semantic and formal derivation of the Common Slavic root *by- (as in the Polish verb być) in the Polish language based on its two different semantic components: 1 . 'to exist, to be somewhere' and 2. 'to have some attribute'; 'to be somebody'.

The analyses lead to the conclusion that *by- (in the derivatives from być) has extremely high frequency both in the vocabulary and in the texts, and as such constitutes an important element of the Polish lexical and syntactic system.

Keywords: semantic derivation; Pol. być

${ }^{2}$ Chciałabym w tym miejscu wyrazić moją wdzięczność i uznanie dla prof. W. Borysia i jego Stownika etymologicznego języka polskiego. Pisząc ten tekst, a i wiele innych moich tekstów, in partibus infidelium nie mogłam obejść się bez tego Słownika, który przynosi informację znacznie bogatszą - tak w sensie historycznym, jak i geograficznym - od samego wywodu etymologicznego. 